\begin{tabular}{c}
\hline TÜRK \\
TARIM ve DOĞA BILIMLERI \\
DERGISI \\
\hline \hline
\end{tabular}

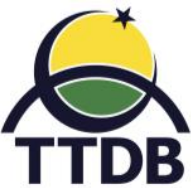

www.dergipark.gov.tr/turkjans

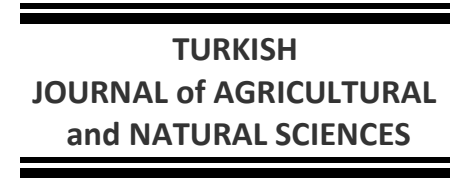

Araştırma Makalesi

\title{
Sulu Koşullarda Bazı Ekmeklik Buğday (Triticum aestivum L.) Genotiplerinin Tarımsal Özellikler Bakımından Değerlendirilmesi
}

\author{
Mehmet KARAMAN*
}

Muş Alparslan Üniversitesi, Uygulamalı Bilimler Fakültesi, Bitkisel Üretim ve Teknolojileri Bölümü. Muş

*Sorumlu yazar: karaman2178@hotmail.com

Geliş Tarihi: 19.11.2018

Düzeltme Geliş Tarihi: 15.02.2019

Kabul Tarihi: 20.03.2019

Özet

Çalışma, 2014-2015 yetiştirme sezonunda sulu koşullarda tesadüf blokları deneme desenine göre 4 tekerrürlü olarak Diyarbakır ve Ceylanpınar'da (E1 ve E2) yürütülmüştür. Araştırmada amaç, tescil adayı olabilecek hatları belirlemektir. Materyal olarak ileri kademeye getirilmiş 20 ekmeklik buğday hattı ve 5 kontrol çeşidi kullanılmıştır. İncelenen tüm özellikler bakımından \%1 düzeyinde önemli farklılıklar tespit edilmiştir. Analiz sonuçlarına göre; tane veriminde (TV) G12 (961.5 kg da-1), hektolitre ağırlığında (HL) G3 (86.0 kg hl-1) ve G7 (86.0 kg hl${ }^{-1}$ ), bin tane ağırlığında (BTA) G12 (49.5 g) protein oranında (PR), G9 (\%15), G11 (\%15), Cemre (\%15), Sagittario (\%15) ve G21 (\%15), sedimantasyonda (Zel) (ZS), G21 (60.5 ml)'in öne çıktığı görülmüştür. Çalışma sonucunda G3, G8 ve G12'nin çeşit adayı olabileceği belirlenirken, ilgili özellikler yönünden öne çıkan genotiplerin ıslah programlarında ebeveyn olarak değerlendirilmesi gerektiği sonucuna varılmıştır.

Anahtar kelimeler: Buğday, kalite, verim, GGE-biplot.

\section{The Evaluation Terms of Agricultural Properties of Some Bread Wheat (Triticum aestivum L.) Genotypes in Irrigated Conditions}

\begin{abstract}
This study was conducted in randomized complete block design with 4 replications in Diyarbakir and Ceylanpinar (E1 and E2) irrigation conditions during 2014-2015 growing season. The aim of the study is to determine the lines that can be candidate for registration. 20 bread wheat advanced lines and 5 checks were used as materials. Significant differences were detected at $1 \%$ in terms of all the properties examined. Analysis results were evaluated; the lines G21 $(60.5 \mathrm{ml})$ for Zeleny sedimentation (ZS), G9 (15\%), G11 (15\%), Cemre (15\%), Sagittario (15\%) ve G21 (15\%) for protein content (PR), G12 (49.5 g) for thousand grain weight (TGW), G3 $\left(86.0 \mathrm{~kg} \mathrm{hl}^{-1}\right.$ ) and $\mathrm{G} 7\left(86.0 \mathrm{~kg} \mathrm{~h}^{-1}\right)$ for hectoliter weight (HW), G12 (961.5 kg da-1) for grain yield (GY) are best genotypes. As a result of the study, it was determined that G3, G8 and G12 could be a candidate of variety. It is concluded that the genotypes that are prominent in terms of their characteristics should be evaluated as a parent in the breeding programs.
\end{abstract}

Key words: Wheat, quality, yield, GGE-biplot.

Giriş

Tahıllar içerisinde buğday, temel besin maddesi olması ve işlenerek farklı mamuller halinde tüketilebilmesi yönüyle yüzyıllardan beri önemini korumaktadır. Dünyada ekilebilir alanların her geçen gün azalması, birim alandan elde edilen ürün miktarını artırmayı zorunlu hale getirmiştir. $\mathrm{Bu}$ durum çeşit geliştirmeyi hedefleyen Islah programlarının birim alandan elde edilecek tane verimi hedeflerini etkilemiştir. Buğday, 220.4 milyon hektar ekim alanı ve 729.0 milyon ton üretim miktarı ile tahıllarda ekim alanında birinci, üretimde üçüncü sırada yer almaktadır (Anonim, 2017). Ülkemizde buğday ekim alanı 7.7 milyon hektar iken, üretimin 20.6 milyon ton olduğu bildirilmiştir (TÜiK, 2017). Ayrıca, toplam buğday 
ekiliş oranının \% 83.9'u ve üretimin ise \% 82.4'nün ekmeklik buğdaya ait olduğu, ekmeklik buğday veriminin ise $266 \mathrm{~kg} \mathrm{da}^{-1}$ olduğu bildirilmiştir (TÜiK, 2017).

Genotipler yağışa dayalı koşullarda yetiştirildiğinde bazı yıllarda yeterli miktarda yağış gerçekleşmemesi nedeniyle verim ve kalite performanslarını tam olarak gösterememektedir. Buğday yetiştiriciliğinde sulama imkânının olmadığı durumlarda yetersiz miktardaki yağış verim ve kalitenin olumsuz yönde etkilenmesine, teknolojik kalite parametrelerinden olan bin tane ağırlığının da düşük olmasına ve bu durumda un verimi de etkilenmektedir (Aktaş, 2014). Buğdayda iklim ve toprak gibi dış etkenler kaliteyi oluşturan fiziksel, kimyasal ve teknolojik özellikler üzerinde etkili olmaktadır (Atlı, 1999).

Biplot analizi çok değişkenli satır ve sütun verilerini grafik olarak göstermesi nedeniyle Çevre ve genotip etkilerinin analizinde yaygın olarak kullanılan bir yöntemdir (Gabriel, 1971). Varyans tabloları ana bileşenlerini satır ve sütun faktörlerini çift yönlü olarak etkileşimini belirlemek ve değişkenleri göstermek için kullanılmaktadır. Tekil değer ayrışımının çok değişkenli grafik teknikleri için temel olarak kullanılabileceği bildirilmiştir (Lipkovich ve Smith, 2002).
Biplot analiz yöntemi ve grafiği çok farklı amaçlar için kullanılmakla birlikte, bu çalışmada ele alınan 5 özellik arasındaki ilişkileri görsel olarak mukayese etmede ve her bir özellik açısından öne çıkan genotipleri görsel olarak belirlemek amacıyla kullanılmıştır. Genotip özellikler arası ilişkiyi inceleyen biplot analizi söz konusu çoklu özellik etkilerini ortaya çıkarmada ve aynı zamanda tek bir özellik bakımından öne çıkan genotipleri görsel olarak belirlemeyi sağlayabilen etkili bir yöntemdir (Karaman ve ark., 2016).

Araştırma Diyarbakır ve Ceylanpınar lokasyonlarında sulu koşullara uygun ekmeklik buğday genotiplerinin, tane verimi ve kalitesi yönünden tescil adayı olabilecek hatların belirlenmesi amacıyla yürütülmüştür.

\section{Materyal ve Yöntem}

Araştırma, ileri kademede 20 hat ile 5 kontrol ekmeklik buğday çeşidi 2014-2015 üretim sezonunda sulu koşullarda Diyarbakır (E1= 3793' enlem; 40²5' boylam; $599 \mathrm{~m}$ rakım) ve Ceylanpınar (E2 $=36^{\circ} 85^{\prime}$ enlem; $40^{\circ} 04^{\prime}$ ' boylam; 366 $\mathrm{m}$ rakım )'da yürütülmüştür. Deneme parselleri 1.2 metre eninde, 5 metre uzunluğunda ve hasatta parsel alanı $6 \mathrm{~m}^{2}$ olacak şekilde ekim yapılmıştır. Ekimde metrekareye 450 adet tohum kullanılmış ve ekim deneme mibzeri ile yapılmıştır.

Çizelge 1. Araştırmada kullanılan genotiplerin melez ve pedigrileri

\begin{tabular}{|c|c|c|}
\hline Genotip No & Melez/Pedigri & Orijin \\
\hline 1 & Qamar-4 Cmss97m03159t-040y-0b-0ap-2ap-0aps-0ap... & CIMMYT \\
\hline 2 & D67.2/Parana 66.270//Ae.Squarrosa (320)/3/Cunnıngh... & CIMMYT \\
\hline 3 & Cno79//Pf70354/Mus/3/Pastor/4/Bav92/5/Mılan/Kauz//... & CIMMYT \\
\hline 4 & Babax/Ks93u76//Babax/3/2*Sokoll Cmsa06m00008t-024 & CIMMYT \\
\hline Dinc & Kontrol & GAP UTAEM \\
\hline 6 & D67.2/Parana 66.270//Ae.Squarrosa (320)/3/Cunnıngham. & CIMMYT \\
\hline 7 & Krıchauff/2*Pastor/4/Mılan/Kauz//Prınıa/3/Bav92cms... & CIMMYT \\
\hline 8 & Heılo//Sunco/2*PastorCmsa06y00492s-040zty-040ztm... & CIMMYT \\
\hline 9 & Chıh95.7.4//Inqalab 91*2/Kukuna Ptss06ghb00007s-0y... & CIMMYT \\
\hline Pehlivan & Kontrol & TTAEM \\
\hline 11 & Kachu \#1/Kırıtatı//Kachu Cmss06y00778t-099topm-099. & CIMMYT \\
\hline 12 & Saual/Yanac//Saual Cmss06y00783t-099topm-099y... & CIMMYT \\
\hline 13 & Prl/2*Pastor*2//Fh6-1-7 Cmss06y00793t-099topm-099y & CIMMYT \\
\hline 14 & Frncln/Rolf07cmss06b00013s-0y-099ztm-099y-099m... & CIMMYT \\
\hline Cemre & Kontrol & GAP UTAEM \\
\hline 16 & Becard/Kachu Cmss06b00169s-0y-099ztm-099y-099m... & CIMMYT \\
\hline 17 & Becard/Akurı Cmss06b00411s-0y-099ztm-099y-099m... & CIMMYT \\
\hline 18 & Rolf07*2/5/Reh/Hare//2*Bcn/3/Croc_1/Ae.Squarrosa ... & CIMMYT \\
\hline 19 & Usher-16 Crow's'/Bow's'-1994/95//Asfoor-5 Icw01-00257 & CIMMYT \\
\hline Sagittario & Kontrol & TASACO T. \\
\hline 21 & Croc 1/Ae.Squarrosa(213)//Pgo/3/Cmh81.38/2*Kauz/4... & CIMMYT \\
\hline 22 & Chen/Aegılops Squarrosa (Taus)//Bcn/3/Bav92/4... & CIMMYT \\
\hline 23 & Mısket-12-Btı735/Achtar//Asfoor-1ıcw01-00164-0ap... & CIMMYT \\
\hline 24 & Rebwah-12/Zemamra-8-Rebwah-12/Zemamra-8ıcw01... & CIMMYT \\
\hline Adana-99 & Kontrol & DATAEM \\
\hline
\end{tabular}

Denemelerde saf madde üzerinden $16 \mathrm{~kg}$ $\mathrm{da}^{-1}$ saf azot $(\mathrm{N})$ ve $6 \mathrm{~kg} \mathrm{da}^{-1}$ saf fosfor $\left(\mathrm{P}_{2} \mathrm{O}_{5}\right)$ hesabıyla gübreleme yapılmıştır. Fosfor $\left(\mathrm{P}_{2} \mathrm{O}_{5}\right)^{\prime}$ un tamamı ekim ile beraber, azot $(\mathrm{N})$ ise ekimde $6 \mathrm{~kg}$ $\mathrm{da}^{-1}$ ve kardeşlenme dönemi sonunda $10 \mathrm{~kg} \mathrm{da}^{-1}$ olarak uygulanmıştır. Diyarbakır deneme arazisinin 
toprak yapısı; killi, PH: 8.1, organik madde miktarı: 0.98, su ile doygunluk oranının ise (\%): 75.9 olduğu görülmüştür (Anonim, 2018). 2014-2015 sezonunda Diyarbakır'da $583 \mathrm{~mm}$ yağış gerçekleşirken, uzun yıllar ortalaması olan 484 mm'nin üzerinde yağış meydana gelmiştir. Ortalamalar üzerinden maksimum sıcaklık $21.3{ }^{\circ} \mathrm{C}$, minimum sıcaklık $8.1{ }^{\circ} \mathrm{C}$, nem oranı \% 61.6 olmuştur (Anonim, 2016). Ceylanpınar lokasyonunda ise $306.4 \mathrm{~mm}$ ile uzun yıllar ortalamasının (263 $\mathrm{mm})$ üzerinde yağış gerçekleşmiştir. Bu lokasyonda uzun yıllar sıcaklık ortalaması $18.3{ }^{\circ} \mathrm{C}$, ortalama nem oranını ise \% 58.6 olarak gerçekleşmiştir (Anonim, 2015). Çalışmada, bitki gelişim dönemleri dikkate alınarak (Zadoks ve ark., 1974), genotipler gebecik (Zadoks 43) ve süt olum başlangıcı (Zadoks 70) dönemde olmak üzere metrekareye $100 \mathrm{~mm}$ su denk gelecek şekilde toplamda $2 \mathrm{kez}$ salma sulama ile sulanmıştır. Ayrıca yabancı otların 2-4 yapraklı olduğu dönemde dar ve geniş yapraklı yabancı otlara karşı herbisit kullanılmış olup, hasat parsel biçerdöveri ile yapılmıştır.

Araştırmada kullanılan genotiplerin melez ve pedigrileri Çizelge 1 'de verilmiştir. Araştırmada, bin tane ağırlığı (BTA) 1000 adet tohumun gram olarak ağırlığını belirleyerek, hektolitre ağırlığı (HL) ise 1 litrelik kaptaki tohumun ağırlığına ait değeri 100 ile çarparak belirlenmiştir (Anonim, 2001). Protein oranı (PR) (\%); (NIR) AACC 39-10 (Anonim, 1990)'a; zeleny sedimantasyon (ZS) analizi; ICC-No. 115 (Anonim, 1982) metoduna göre yapılmıştır. Elde edilen verilerin varyans analizleri JMP 5.0 paket programı kullanılarak yapılmıştır. Ortalamalar arasındaki farklılıklar ise LSD testi ile $(p \leq 0.01$ ve $p \leq 0.05)$ incelenmiştir. Ayrıca özellikler arası ve genotip-özellik ilişkilerini değerlendirmek amacıyla GGE-biplot analizi, GenStat $12^{\text {th }}$ istatistik paket programı kullanılarak yapılmıştır (GENSTAT, 2009). Öne çıkan genotipler görsel olarak gösterilmiştir.

\section{Bulgular ve Tartışma}

Araştırmada iki lokasyona ait değerler üzerinden yapılan birleşik varyans analiz sonuçlarına göre araştırılan bütün özellikler için genotipler arasındaki fark 0.01 düzeyinde istatistiki olarak önemli bulunmuştur.

Birleşik varyans analizi sonuçlarına göre denemeye ait ortalama TV değeri $776.7 \mathrm{~kg} \mathrm{da}^{-1}$ bulunmuştur. Araştırmada, ortalama ve lokasyonlar bazında en yüksek TV, G12 (961.5 kg $\left.\mathrm{da}^{-1}\right)^{\prime}$ den elde edilmiştir. Birçok araştırmacı tarafından, TV'nin birçok gen ile kontrol edilen bir özellik olduğu, aynı zamanda farklı yılların, çevrelerin ve gerçekleşen yağış miktarının TV açısından büyük bir öneme sahip olduğu bildirilmiştir (Mut ve ark., 2005; Kaydan ve Yağmur, 2008; Kılıç ve ark., 2018; Karaman, 2019). Fakat bu çalışmada lokasyonlar arasında önemli bir fark görülmemiştir. Çalışmamız bu yönü ile farklılık göstermektedir. Bu durum, çalışmanın yapıldığı lokasyonlar farklı iklim yapısına sahip olmasına rağmen tane verimi bakımından genotiplerin değişen çevre koşullarından çok fazla etkilenmediği şeklinde düşünülmektedir.

\section{Ranking biplot (Total - 100.00\%)}

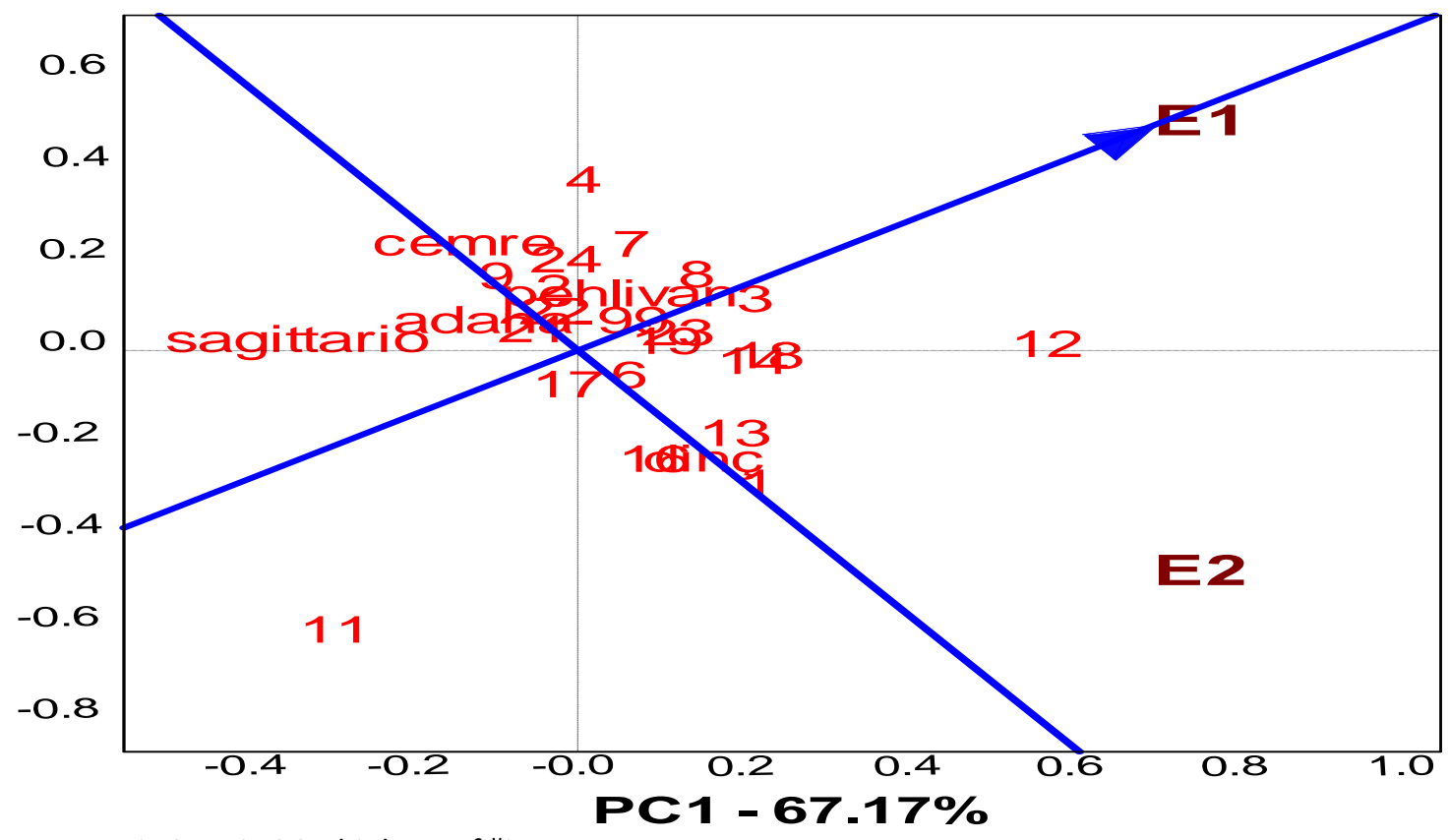

Şekil 1. Tane verimine ait GGE-biplot grafiği. 
TV bakımından genotiplerin stabilitesini ve verim sıralamasının görsel olarak sunumu Şekil 1'de verilmiştir. AEC (Koordinatların ortalama merkezi) yöntemine göre ortalama TV'yi temsil eden ve ekseni ortadan kesen çizginin sağında yer alan (PC1 değeri sıfırdan yüksek olan) genotipler ortalamadan daha yüksek tane verimine sahip olurken, diğer genotiplerin ise ortalamadan daha düşük değere sahip olduğu, genotipin orijini yatay olarak kesen çizgiye yakın yerde olması veya PC2 değerinin sıfıra yakın olması aynı zamanda stabil bir genotip olduğunu ifade etmiştir (Aktaş ve ark., 2017a). Buna göre biplot grafiği incelendiğinde G12 stabilite çizgisinin en sağında yer alan genotip olması sebebiyle en yüksek tane verimine sahip olduğu görülürken, G3 ve G8'in tane verimi bakımından ümit var olduğu aynı zamanda stabilite çizgisine çok yakın olmasından dolayı G12'den daha stabil oldukları görülmüştür.

Ekmeklik buğday genotiplerinin ortalama hektolitre değerleri Çizelge 2'de verilmiştir. Araştırmada, ortalama hektolitre $83.7 \mathrm{~kg} \mathrm{hl}^{-1}$ bulunmuştur. Çalışmada $\mathrm{G} 3\left(86.0 \mathrm{~kg} \mathrm{hl}^{-1}\right)$ ve $\mathrm{G} 7$ (86.0 $\mathrm{kg} \mathrm{hl}^{-1}$ ) en yüksek ortalama $\mathrm{HL}^{\prime}$ ye sahip olmuştur. Diyarbakır koşullarında G3 (86.0 kg hl-1) ve $\mathrm{G} 7\left(86.0 \mathrm{~kg} \mathrm{hl}^{-1}\right.$ ) $\mathrm{HL}$ bakımından öne çıkarken, Ceylanpınar lokasyonunda aynı genotiplerin yanı sıra G8 (86.0 kg hl$\left.{ }^{-1}\right)^{\prime}$ de ön sırada yer almıştır. Konya koşullarında ekmeklik buğdayda yürütülen bir çalışmada $\mathrm{HL}^{\prime}$ ye ait deneme ortalamasının 76.9 $\mathrm{kg} \mathrm{hl}^{-1}$ olduğu tespit edilmiştir (Aydoğan ve Soylu, 2017).

Çizelge 2. İki farklı çevrede incelenen özelliklere ilişkin belirlenen değerler

\begin{tabular}{|c|c|c|c|c|c|c|c|c|c|c|c|c|c|c|c|}
\hline \multirow{3}{*}{ Genotip (G) } & \multirow{2}{*}{\multicolumn{3}{|c|}{$\begin{array}{c}\text { TV }\left(\mathrm{kg} \mathrm{da}^{-1}\right) \\
G \times \mathrm{L}\end{array}$}} & \multicolumn{3}{|c|}{$\mathrm{HL}\left(\mathrm{kg} \mathrm{hl}^{-1}\right)$} & \multicolumn{3}{|c|}{ BTA (g) } & \multicolumn{3}{|c|}{ PR (\%) } & \multicolumn{3}{|c|}{$\mathrm{ZS}(\mathrm{ml})$} \\
\hline & & & & \multicolumn{3}{|c|}{$\mathbf{G} \times \mathbf{L}$} & \multicolumn{3}{|c|}{$\mathbf{G} \times \mathbf{L}$} & \multicolumn{3}{|c|}{$\mathbf{G} \times \mathbf{L}$} & \multicolumn{3}{|c|}{$\mathbf{G} \times \mathbf{L}$} \\
\hline & \multicolumn{3}{|c|}{$E 2$} & E1 & E2 & Ort. & E1 & E2 & Ort. & E1 & E2 & Ort. & E1 & E2 & Ort. \\
\hline G1 & 917 & 724 & 820.5 & 85 & 84 & 84.5 & 38 & 41 & 39.5 & 10 & 15 & 12.5 & 24 & 42 & 33.0 \\
\hline $\mathrm{G} 2$ & 790 & 747 & 768.5 & 85 & 84 & 84.5 & 42 & 45 & 43.5 & 11 & 14 & 12.5 & 30 & 44 & 37.0 \\
\hline G3 & 851 & 855 & 853.0 & 86 & 86 & 86.0 & 44 & 50 & 47.0 & 12 & 15 & 13.5 & 30 & 35 & 32.5 \\
\hline G4 & 760 & 842 & 801.0 & 82 & 83 & 82.5 & 34 & 37 & 35.5 & 11 & 14 & 12.5 & 30 & 47 & 38.5 \\
\hline Dinç & 881 & 687 & 784.0 & 85 & 85 & 85.0 & 35 & 37 & 36.0 & 12 & 15 & 13.5 & 23 & 38 & 30.5 \\
\hline G6 & 842 & 728 & 785.0 & 84 & 84 & 84.0 & 40 & 43 & 41.5 & 11 & 15 & 13.0 & 24 & 38 & 31.0 \\
\hline G7 & 796 & 823 & 809.5 & 86 & 86 & 86.0 & 42 & 45 & 43.5 & 12 & 15 & 13.5 & 27 & 32 & 29.5 \\
\hline G8 & 826 & 839 & 832.5 & 85 & 86 & 85.5 & 37 & 40 & 38.5 & 13 & 16 & 14.5 & 20 & 44 & 32.0 \\
\hline G9 & 770 & 723 & 746.5 & 84 & 85 & 84.5 & 41 & 44 & 42.5 & 14 & 16 & 15.0 & 27 & 36 & 31.5 \\
\hline Pehlivan & 782 & 724 & 753.0 & 84 & 83 & 83.5 & 44 & 45 & 44.5 & 12 & 15 & 13.5 & 25 & 36 & 30.5 \\
\hline G11 & 844 & 368 & 606.0 & 84 & 83 & 83.5 & 44 & 46 & 45.0 & 12 & 18 & 15.0 & 25 & 34 & 29.5 \\
\hline G12 & 944 & 979 & 961.5 & 83 & 84 & 83.5 & 47 & 52 & 49.5 & 12 & 15 & 13.5 & 23 & 38 & 30.5 \\
\hline G13 & 887 & 737 & 812.0 & 83 & 83 & 83.0 & 45 & 50 & 47.5 & 12 & 15 & 13.5 & 25 & 39 & 32.0 \\
\hline G14 & 867 & 799 & 833.0 & 82 & 83 & 82.5 & 41 & 44 & 42.5 & 12 & 16 & 14.0 & 31 & 45 & 38.0 \\
\hline Cemre & 728 & 686 & 707.0 & 83 & 82 & 82.5 & 36 & 42 & 39.0 & 13 & 17 & 15.0 & 22 & 40 & 31.0 \\
\hline G16 & 874 & 672 & 773.0 & 85 & 84 & 84.5 & 47 & 47 & 47.0 & 13 & 16 & 14.5 & 25 & 36 & 30.5 \\
\hline G17 & 823 & 676 & 749.5 & 82 & 82 & 82.0 & 40 & 43 & 41.5 & 13 & 16 & 14.5 & 22 & 42 & 32.0 \\
\hline G18 & 869 & 811 & 840.0 & 83 & 83 & 83.0 & 42 & 45 & 43.5 & 13 & 16 & 14.5 & 34 & 48 & 41.0 \\
\hline G19 & 836 & 764 & 800.0 & 82 & 81 & 81.5 & 38 & 37 & 37.5 & 12 & 17 & 14.5 & 21 & 39 & 30.0 \\
\hline Sagittario & 703 & 499 & 601.0 & 83 & 83 & 83.0 & 38 & 40 & 39.0 & 13 & 17 & 15.0 & 25 & 51 & 38.0 \\
\hline G21 & 794 & 696 & 745.0 & 85 & 84 & 84.5 & 41 & 41 & 41.0 & 13 & 17 & 15.0 & 33 & 59 & 46.0 \\
\hline G22 & 794 & 721 & 757.5 & 83 & 82 & 82.5 & 44 & 46 & 45.0 & 12 & 16 & 14.0 & 24 & 36 & 30.0 \\
\hline G23 & 836 & 776 & 806.0 & 83 & 82 & 82.5 & 41 & 46 & 43.5 & 12 & 17 & 14.5 & 21 & 32 & 26.5 \\
\hline G24 & 778 & 764 & 771.0 & 85 & 84 & 84.5 & 44 & 48 & 46.0 & 11 & 15 & 13.0 & 22 & 37 & 29.5 \\
\hline Adana-99 & 761 & 643 & 702.0 & 84 & 85 & 84.5 & 35 & 38 & 36.5 & 12 & 16 & 14.0 & 27 & 43 & 35.0 \\
\hline AÖF(0.05): & \multicolumn{2}{|c|}{$104.2^{* *}$} & $73.6^{* *}$ & \multicolumn{2}{|c|}{ Ö.D. } & $1.0 * *$ & \multicolumn{2}{|c|}{ Ö.D. } & $3.0 * *$ & \multicolumn{2}{|c|}{$1.1^{* *}$} & $0.8^{* *}$ & \multicolumn{2}{|c|}{ Ö.D. } & $8.1^{* *}$ \\
\hline Lok.Ort.: & 822 & 731 & & 84 & 84 & & 41 & 44 & & 12 & 16 & & 41 & 52 & \\
\hline Genel Ort.: & & & 776.7 & & & 83.7 & & & 42.2 & & & 13.4 & & & 33.0 \\
\hline AÖF.Lok(0.05) & \multicolumn{3}{|c|}{ Ö.D. } & \multicolumn{3}{|c|}{ Ö.D. } & \multicolumn{3}{|c|}{ Ö.D. } & \multicolumn{3}{|c|}{$0.9 * *$} & \multicolumn{3}{|c|}{$4.5^{* *}$} \\
\hline D.K.(\%): & \multicolumn{3}{|c|}{9.6} & \multicolumn{3}{|c|}{0.8} & \multicolumn{3}{|c|}{5.0} & \multicolumn{3}{|c|}{3.9} & & 12.2 & \\
\hline
\end{tabular}

Not: **, *: \%1 ve \%5 seviyesinde önemli, E1: Diyarbakır, E2: Ceylanpınar, L.:Lokasyon, Ort.: Ortalama, G; Genotip, Ö.D.: Önemli değil.

Bu çalışmada hektolitreye ait deneme ortalamasının daha yüksek olmasının çalışmanın yürütüldüğü lokasyonlara ait yağış miktarının fazlalığından, iki dönemde yapılan sulamadan ve çalışmada kullanılan genotiplerin farklılığından kaynaklandığı düşünülmektedir.

Hektolitre bakımından 2 lokasyona ait veriler kullanılarak oluşturulan Biplot grafiğine göre 
(Şekil 2.) G7 en iyi hektolitreye sahipken, G3 ve G8 genotipleri de ön sıralarda yer almıştır. Ayrıca Biplot grafiğinde görüldüğü gibi G3 ve G7 stabilite çizgisinin üzerinde yer almaktadır. Bundan dolayı bu genotiplerin çalışmada hektolitre ağırlığına göre en stabil genotipler olduğunu söylemek mümkündür. Karaman ve ark. (2017), yaptıkları çalışmada GGE-Biplot stabilite grafiğinde araştırılan özellik bakımından stabilite çizgisinin en sağında yer alan genotiplerin ilgili özellik bakımından ön sırada yer aldığını, stabilite çizgisine en yakın olan genotiplerin ise en stabil genotipler olduğunu bildirmişlerdir.

\section{Ranking biplot (Total - 100.00\%)}

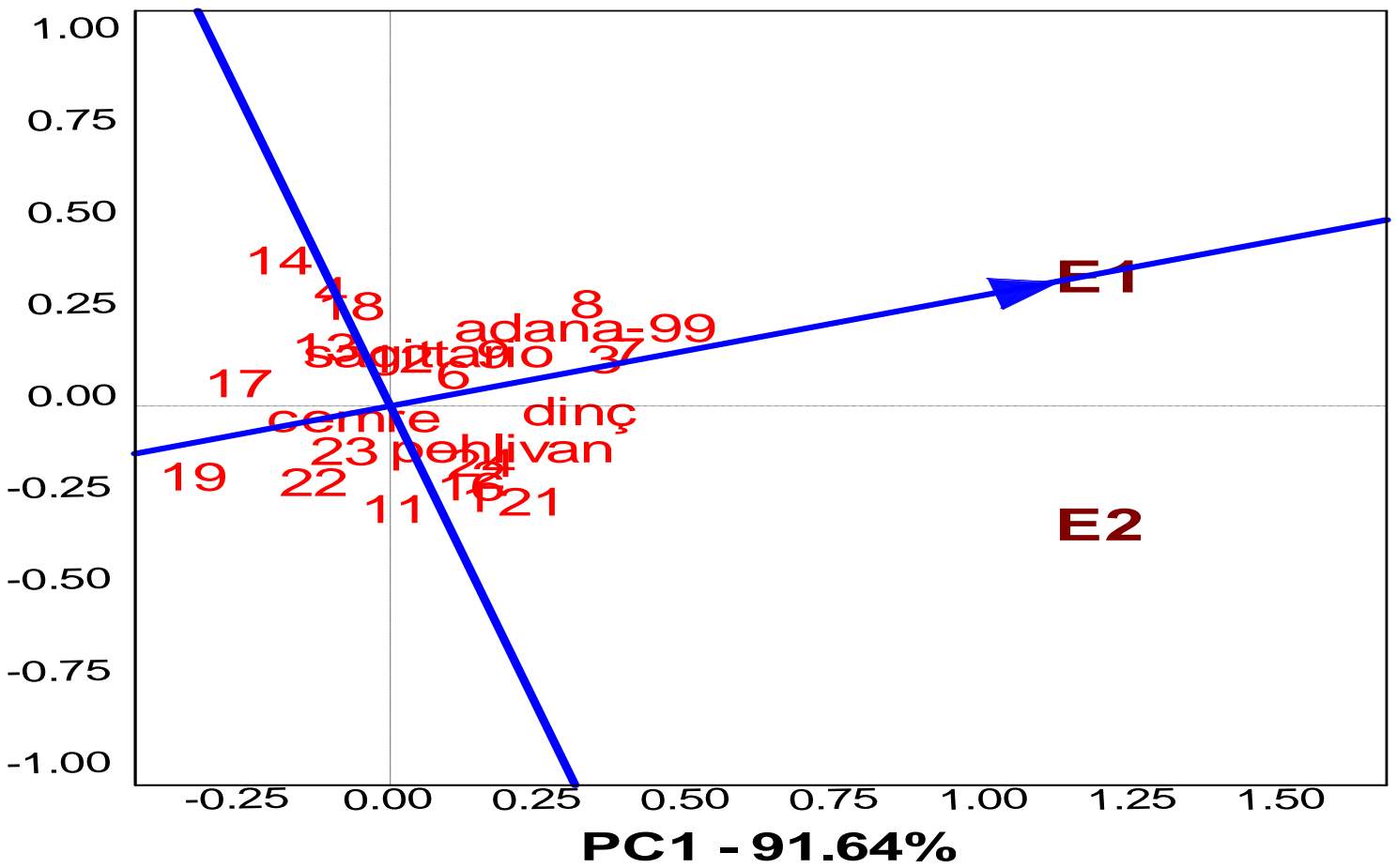

Şekil 2. Hektolitre ağırlığına ait GGE-biplot grafiği.

\section{Ranking biplot (Total - 100.00\%)}

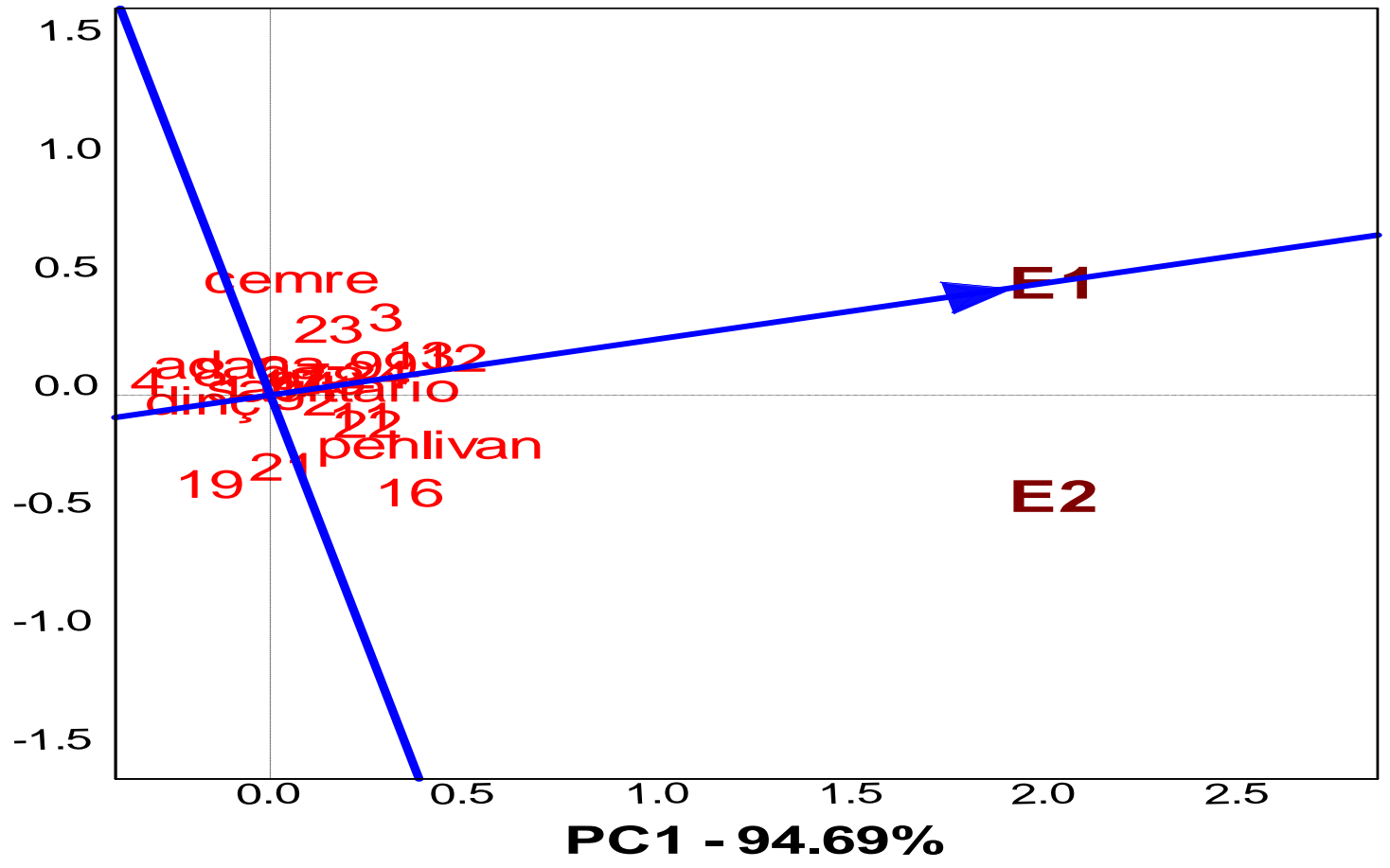

Şekil 3. Bin tane ağırlığına ait GGE-biplot grafiği. 
Araştırmada sulu koşullarda genotiplerin ortalama 1000-tane ağırlığı (BTA) değerinin $42.2 \mathrm{~g}$ olduğu belirlenmiştir. Genotipler içerisinde ortalama en yüksek BTA değeri G12 (49.5 g)'de görülmüştür. Ayrıca hem Diyarbakır hem de Ceylanpınar lokasyonlarında en yüksek bin tane ağırlığına sahip genotipin G12 (47 ve 52 g) olduğu belirlenmiştir. Tokat-Kazova'da sulu koşullarda ekmeklik buğdayda yürütülen bir çalışmada BTA'nın 40.1 g ile 52.7 g arasında değiştiği bildirilmiştir (Sakin ve ark., 2017). Elde edilen değerler yönünden çalışmalar benzerlik göstermektedir. Bin tane ağılığına ait biplot grafiği incelendiğinde (Şekil 3) G12'nin en yüksek BTA'ya sahip olduğu ve aynı zamanda stabilite çizgisinin hemen üzerinde yer alması sebebiyle en stabil genotip olduğu belirlenmiştir. Ayrıca, G3, G13 ve G16 hatları da BTA bakımından ön sırada yer almıştır.

Protein oranı bakımından deneme ortalaması \% 13.4 olmuş ve ortalama protein oranı bakımından birçok genotip öne çıkmıştır (G9, G11, Cemre, Sagittario ve G21). Diyarbakır lokasyonunda en yüksek protein değeri, G9 (\% 14)'da olduğu belirlenirken, Ceylanpınar lokasyonunda G11 (\% 18) en yüksek protein değerine sahip olmuştur. Ekmeklik buğday genotiplerinin protein değerine ait veriler Çizelge 2'de verilmiştir. Orta Anadolu koşullarında kışlık ekmeklik buğdayda yapılan bir çalışmada PR ortalama değerinin \% 13.1 olduğu belirlenmiştir (Şahin ve ark., 2016). PR, çevre şartlarından önemli ölçüde etkilenen bir özelliktir. Bu çalışmada ortalama protein değerlerinin daha yüksek olmasının önemli ölçüde çevre şartlarından ve çalışmada kullanılan genotiplerin farklıı̆̆ından kaynaklandığı düşünülmektedir. Diyarbakır ve Ceylanpınar'da yürütülen çalışmada elde edilen veriler bir arada değerlendirilerek oluşturulan biplot grafiği (Şekil 4.) incelendiğinde protein oranı bakımından G11, Sagittario, Cemre ve G9'un ilk sıralarda yer aldığı belirlenmiştir. Ayrıca, G21'in de değerinin iyi olduğu, stabilite çizgisinin çok yakınında yer alması sebebiyle mevcut genotipler içerisinde protein değeri bakımından en stabil genotip olduğu söylenebilir.

\section{Ranking biplot (Total - 100.00\%)}

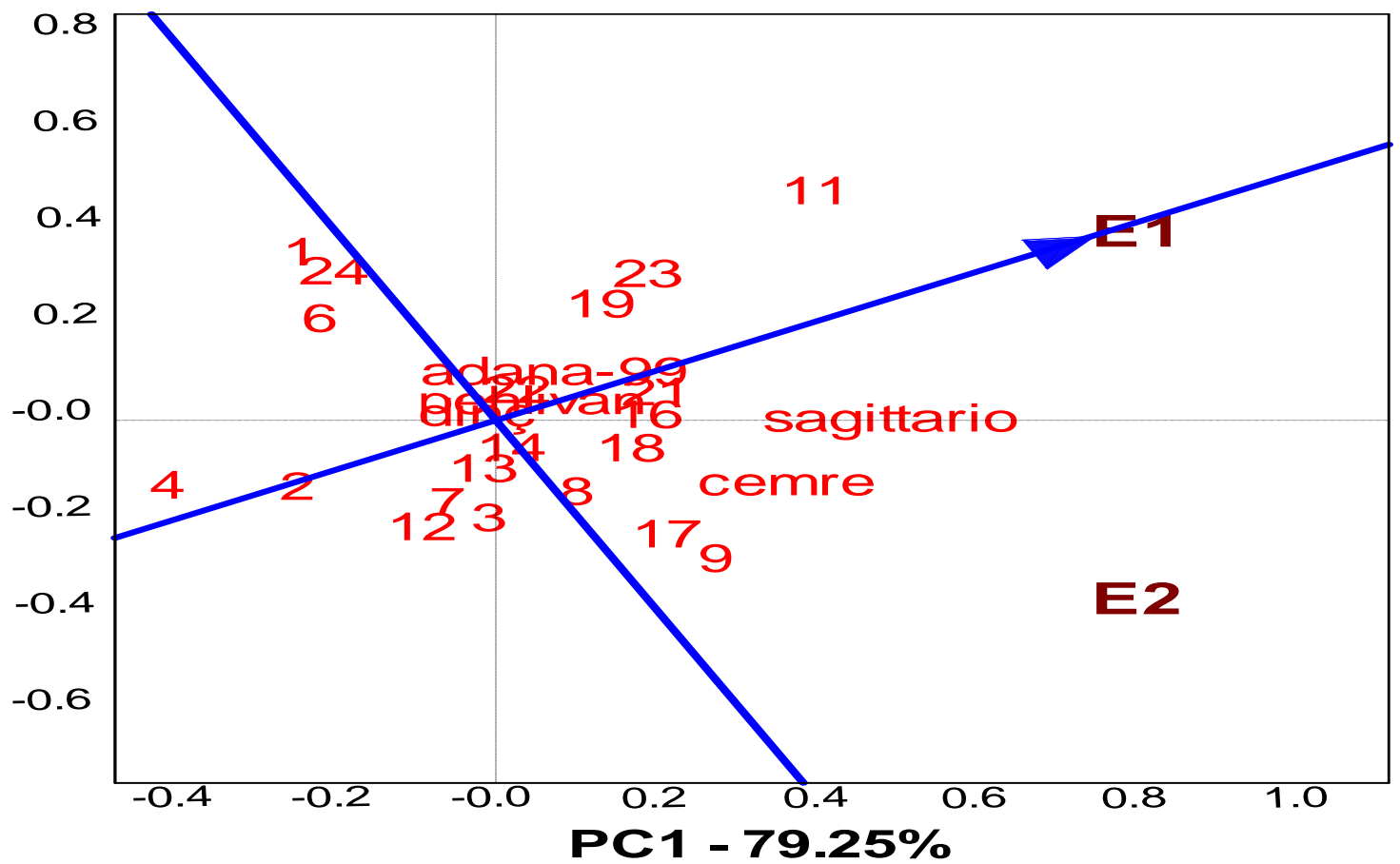

Şekil 4. Protein oranına ait GGE-biplot grafiği.

Sedimantasyon (Zel) değeri bakımından deneme ortalaması $33.0 \mathrm{ml}$ bulunmuştur. En yüksek ortalama sedimantasyon değerine G21 sahip olurken, Diyarbakır lokasyonunda G18 (34 $\mathrm{ml}$ ) ve Ceylanpınar lokasyonunda G21 (59 ml) en yüksek değere ulaşmıştır (Çizelge 2).
Yurdumuzda farklı çevre koşullarında yetiştiriciliği yapılan ve değişik kalıtsal özelliklere sahip buğday çeşitlerinin sedimantasyon değeri 26.0-56.0 $\mathrm{ml}$ arasında değişim gösterdiği bildirilmiştir (Bayram ve ark., 2008; Öztürk ve Gökkuş, 2008; Aktaş ve ark., 2017a). ZS değeri üzerinde çevre faktörlerinin etkisi göz ardı 
edilemez, fakat özellikle genetiksel yapının önemli düzeyde etkili olduğu bildirilmiştir (Atlı ve Koçak, 2007). Çalışma sonucunda oluşturulan biplot grafiğinde görüldüğü üzere (Şekil 5.) sedimantasyon bakımından en yüksek değer G21'den elde edilirken G18, G4 ve Sagittario çeşidinin de ön sıralarda yer aldığı görülmüştür. Ayrıca, G21 hattı diğer genotiplere göre stabilite çizgisine yakın bir konumda yer alması sebebiyle G21'in mevcut genotipler içerisinde ZS değeri en yüksek ve aynı zamanda stabil genotip olduğu söylenebilir.

Ranking biplot (Total - 100.00\%)

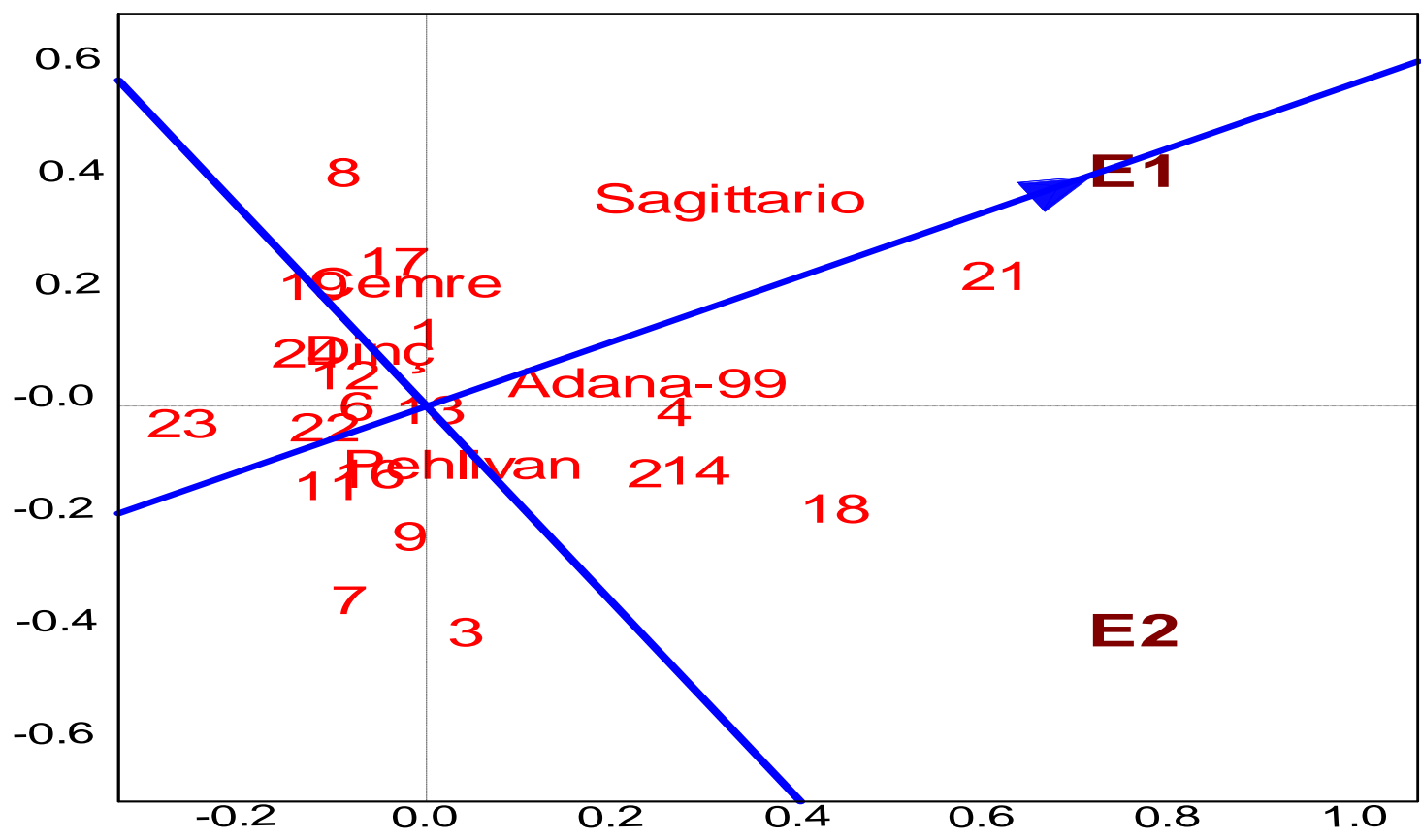

PC1 - $75.25 \%$

Şekil 5. Zeleny Sedimantasyon değerine ait GGE-biplot grafiği.

Scatter plot (Total - 59.66\%)

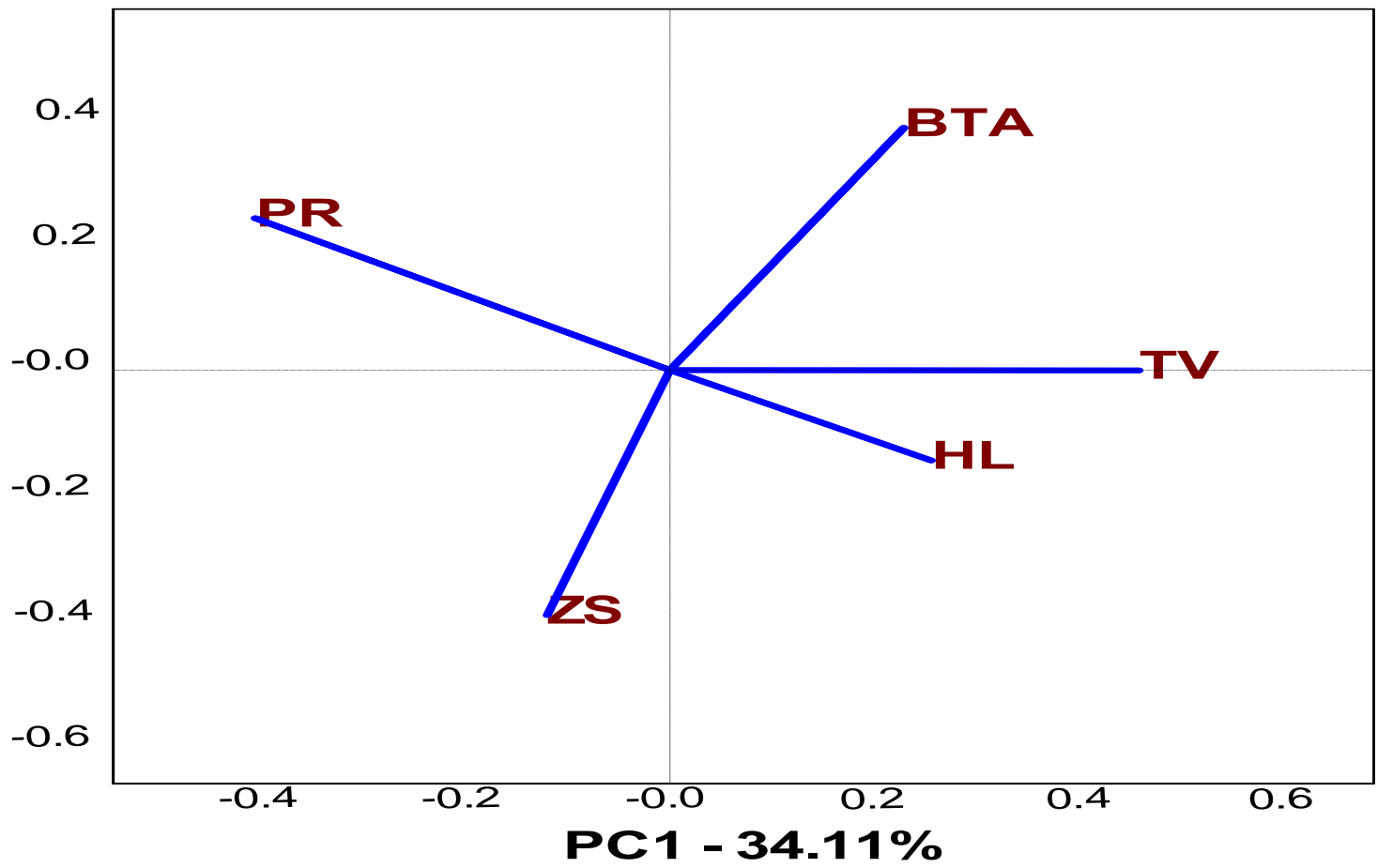

Şekil 6. İncelenen özellikler arası ilişkiyi gösteren GGE-biplot grafiği. 
Tane verimi, hektolitre ve bin tane ağırlığı özelliklerini temsil eden vektörler arasındaki açının 90 dereceden düşük olması, bu karakterler arasında yüksek bir pozitif korelasyon olduğunu göstermektedir (Şekil 6). Protein oranı ve hektolitre ağırlığına ait vektörlerin 180 derece ters yönde yer alması bu özellikler arasında negatif korelasyon olduğu şeklinde yorumlanabilir. Ayrıca, özellikleri temsil eden vektörlerin uzunluğu veya vektörün orijinden uzaklığı da ilgili özellik bakımından genotiplerin varyasyonunu göstermektedir (Abate ve ark., 2015; Aktaş ve ark., 2017b). Buna göre bin tane ağılığı, protein oranı, sedimantasyon ve tane verimine ait vektörlerin uzun veya orijin merkezinden uzak olması sebebiyle genotipler arasında yüksek varyasyon, hektolitre ağırlığına ait vektörün ise kısa veya orijin merkezine yakın olması sebebiyle genotipler arasında düşük varyasyonun olduğu şeklinde yorumlanabilir.

\section{Sonuç ve Öneriler}

2014-2015 ürün yetiştirme sezonunda

Diyarbakır ve Ceylanpınar (E1 ve E2) lokasyonlarında sulu koşullarda yürütülen ekmeklik buğday çalışması sonucunda G3, G8, G12, G14 ve G18 hatlarının verim yönünden iyi olduğu belirlenmiştir. Kalitede ise G3, G7, G8, G11, G12, G21 ve Sagittario'nun iyi değerlere sahip olduğu görülmüştür. Bu genotiplerin verim veya kalite odaklı melezleme programı çalışmalarında ebeveyn olarak kullanılabileceği sonucuna varılmıştır. Çalışmada incelenen tüm parametreler bakımından sulu koşullarda Ceylanpınar lokasyonunda genotiplerin mevcut kapasitelerini daha iyi ortaya koyduğu belirlenmiştir. Ayrıca çalışmada yer alan G3, G8 ve G12'nin incelenen tüm özellikler dikkate alınarak yapılan değerlendirme sonucunda bu hatların tescil adayı olabileceği belirlenmiştir.

\section{Kaynaklar}

Abate, F., Mekbib, F., Dessalegn, F. 2015. GGE biplot analysis of multi-environment yield trials of durum wheat (Triticum turgidum Desf.) genotypes in North Western Ethiopia. American Journal Expanded Agriculture, 8(2): 120-129.

Aktaş, H. 2014 Investigation of Quality Stability and Micro Elements Content of Some Bread Wheat Varieties in Southeast Anatolia Region Conditions. Mustafa Kemal University, Field Crop Department, Ph.D. Thesis, 269p.

Aktaş, H., Erdemci, İ., Karaman, M., Kendal, E., Tekdal, S. 2017a. Bazı kışlık ekmeklik buğday genotiplerinin tane verimi ve bazı kalite özellikleri bakımından GGE Biplot analiz yöntemi İle Değerlendirilmesi. Türk Doğa ve Fen Dergisi, 6(1): 43-49.

Aktaş, H., Karaman, M., Oral, E., Kendal, E., Tekdal, S. 2017b. Bazı ekmeklik buğday genotiplerinin (Triticum aestivum L.) doğal yağış koşullarındaki verim ve kalite parametrelerinin değerlendirilmesi. Tarla Bitkileri Merkez Araştırma Enstitüsü Dergisi, 26(1): 86-95.

Anonim, 1982. ICC-Standart No:115/1. International Association for Cereal Chemistry.

Anonim, 1990. Approved Methods of the American Association of Cereal Chemist, USA.

Anonim, 2001. Serin İklim Tahılları Tarımsal Değerleri Ölçme Talimatı. Tohumluk Tescil ve Sertifikasyon Merkezi, Ankara.

Anonim, 2015. Şanlıurfa Meteoroloji Bölge Müdürlüğü kayıtları. Şanlıurfa uzun yıllar ortalaması (1960- 2016), çalışma yıllarına ait sıcaklık, yağış ve nem değerleri https://www.mgm.gov.tr/veridegerlendirm e/il-veilceler-istatistik. Şanlıurfa.

Anonim, 2016. Diyarbakır Meteoroloji Bölge Müdürlüğü Kayıtları. Diyarbakır.

Anonim, 2017. Food and Agriculture Organization of the United Nations (FAO). http://faostat3.fao.org/download/Q/QC/E.

Anonim, 2018. GAP Uluslararası Tarımsal Araştırma ve Eğitim Merkezi Müdürlüğü Laboratuvarı Kayıtları. Diyarbakır.

Atlı, A. 1999. Buğday ve ürünleri kalitesi. Orta Anadolu'da Hububat Tarımının Sorunları ve Çözüm Yolları Sempozyumu Bildirileri Kitabı, Konya, s. 498-506.

Atlı, A., Koçak, N. 2007. Islah programlarında ekmeklik buğday kalitesinin farklı sedimentasyon testleri ile tahmini. Harran Üniversitesi, Ziraat Fakültesi Dergisi, 8(1): 156.

Aydoğan, S., Soylu, S. 2017. Ekmeklik buğday çeşitlerinin verim ve verim öğeleri ile bazı kalite özelliklerinin belirlenmesi. Tarla Bitkileri Merkez Araştırma Enstitüsü Dergisi, 26(1): 24-30.

Bayram, M.E., Özseven, Demir, L., Orhan, Ş. 2008. Investigation of grain yields and some quality parameters of advanced lines in south Marmara region bread wheat breeding studies. Ülkesel Tahıl Sempozyumu, Konya, 2008. s. 176-784.

Gabriel, K.R. 1971. The Biplot-Graphic Display of Matrices with Application to Principal Component Analysis. Biometrika.

GENSTAT, 2009. GenStat for Windows $\left(12^{\text {th }}\right.$ Edition) Introduction. Vsn International, Hemel Hempstead. 
Karaman, M., Akıncı, C., Yıldırım, M. 2016. Ekmeklik buğdayda morfolojik özellikler ile tane verimi arasındaki ilişkinin biplot analiz yöntemi ile incelenmesi. Tarım Kongresi, Afyon, 8(2): 12-15.

Karaman, M., Aktaş, H., Kendal, E., Başaran, M., Erdemci, i., Tekdal, S., Bayram, S., Doğan, H., Ayana, B. 2017. Ileri kademedeki bazı ekmeklik buğday genotiplerinin verim ve kalite parametreleri yönünden biplot analiz yöntemiyle incelenmesi. Tarla Bitkileri Merkez Araştırma Enstitüsü Dergisi, 26: 4551.

Karaman, M. 2019. Evaluation of bread wheat genotypes in irrigated and rainfed conditions using biplot analysis. Applied Ecology and Environmental Research, 17(1):1431-1450.

Kaydan, D., Yağmur, M. 2008. Van ekolojik koşullarında bazı ekmeklik buğday (Triticum aestivum L.) çeşitlerinin verim ve verim öğeleri üzerine bir araştırma. Tarım Bilimleri Dergisi, 14(4): 350-358.

Kılıç, H., Kendal, E., Aktaş, H. 2018. Evaluation of yield and some quality characters of winter barley (Hordeum vulgare L.) genotypes using biplot analysis. Agriculture \& Forestry, 64(3): 101-111.

Lipkovich, I., Smith E.P. 2002. Biplot and singular value decomposition macros for excel. Department of Statistics Virginia Tech Blacksburg.

Mut, Z., Aydın, N., Özcan, H., Bayramoğlu, O. 2005. Orta Karadeniz Bölgesi'nde ekmeklik buğday (Triticum aestivum L.) genotiplerinin verim ve bazı kalite özelliklerinin belirlenmesi. Gazi Osman Paşa Üniversitesi, Ziraat Fakültesi Dergisi, 22(2): 85-93.

Sakin, M.A., Naneli, İ., İsmailoğlu, A.Y., Özdemir, K. 2017. Tokat Kazova koşullarında bazı ekmeklik buğday (Triticum aestivum L.) çeşitlerinin kuru ve sulu şartlarda verim ile kalite özelliklerinin belirlenmesi. Gazi Osman Paşa Üniversitesi, Ziraat Fakültesi Dergisi, ISSN: 1300-2910 E-ISSN: 2147-8848, 34(Ek Sayı): 87-96.

Şahin, M., Göçmen., Akçacık, A., Aydoğan, S., Yakışır, E. 2016. Orta Anadolu sulu koşullarında bazı kışlık ekmeklik buğday genotiplerinin verim ve kalite performanslarının belirlenmesi. Tarla Bitkileri Merkez Araştırma Enstitüsü Dergisi, 25 (Özel Sayı-1): 19-23.

Öztürk, İ., Gökkuş, A. 2008. The effects of nitrogen fertilization on grain yield and quality in some bread wheat varieties. Ankara
Üniversitesi, Ziraat Fakültesi, Tarım Bilimleri Dergisi, 14(4): 334-340.

TÜiK, 2017. Türkiye İstatistik Kurumu. Bitkisel Üretim İstatistikleri. www.tuik.gov.tr.

Zadoks, J.C., Chang T.T. ve Konzak, C.F. 1974. A decimal code for the growth stages of cereals. Weed Res., 14: 415-421. 